NASA/TM-2002-211328

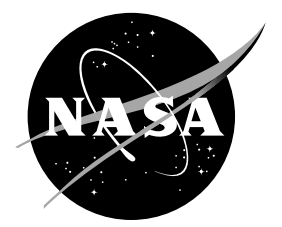

\title{
The Role of Water Vapor and Dissociative Recombination Processes in Solar Array Arc Initiation
}

J. Galofaro

Glenn Research Center, Cleveland, Ohio

B. Vayner

Ohio Aerospace Institute, Brook Park, Ohio

W. Degroot

Siliconlight, Inc., Sunnyvale, California

D. Ferguson

Glenn Research Center, Cleveland, Ohio 
Since its founding, NASA has been dedicated to the advancement of aeronautics and space science. The NASA Scientific and Technical Information (STI) Program Office plays a key part in helping NASA maintain this important role.

The NASA STI Program Office is operated by Langley Research Center, the Lead Center for NASA's scientific and technical information. The NASA STI Program Office provides access to the NASA STI Database, the largest collection of aeronautical and space science STI in the world. The Program Office is also NASA's institutional mechanism for disseminating the results of its research and development activities. These results are published by NASA in the NASA STI Report Series, which includes the following report types:

- $\quad$ TECHNICAL PUBLICATION. Reports of completed research or a major significant phase of research that present the results of NASA programs and include extensive data or theoretical analysis. Includes compilations of significant scientific and technical data and information deemed to be of continuing reference value. NASA's counterpart of peerreviewed formal professional papers but has less stringent limitations on manuscript length and extent of graphic presentations.

- TECHNICAL MEMORANDUM. Scientific and technical findings that are preliminary or of specialized interest, e.g., quick release reports, working papers, and bibliographies that contain minimal annotation. Does not contain extensive analysis.

- CONTRACTOR REPORT. Scientific and technical findings by NASA-sponsored contractors and grantees.
- CONFERENCE PUBLICATION. Collected papers from scientific and technical conferences, symposia, seminars, or other meetings sponsored or cosponsored by NASA.

- SPECIAL PUBLICATION. Scientific, technical, or historical information from NASA programs, projects, and missions, often concerned with subjects having substantial public interest.

- TECHNICAL TRANSLATION. Englishlanguage translations of foreign scientific and technical material pertinent to NASA's mission.

Specialized services that complement the STI Program Office's diverse offerings include creating custom thesauri, building customized data bases, organizing and publishing research results ... even providing videos.

For more information about the NASA STI Program Office, see the following:

- Access the NASA STI Program Home Page at http://www.sti.nasa.gov

- E-mail your question via the Internet to help@sti.nasa.gov

- Fax your question to the NASA Access Help Desk at 301-621-0134

- Telephone the NASA Access Help Desk at 301-621-0390

- Write to:

NASA Access Help Desk

NASA Center for AeroSpace Information 7121 Standard Drive

Hanover, MD 21076 
NASA/TM-2002-211328

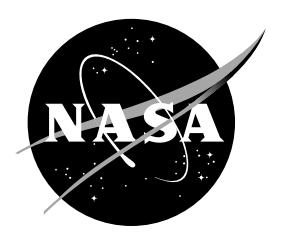

\section{The Role of Water Vapor and Dissociative Recombination Processes in Solar Array Arc Initiation}

J. Galofaro

Glenn Research Center, Cleveland, Ohio

B. Vayner

Ohio Aerospace Institute, Brook Park, Ohio

W. Degroot

Siliconlight, Inc., Sunnyvale, California

D. Ferguson

Glenn Research Center, Cleveland, Ohio

Prepared for the

40th Aerospace Sciences Meeting and Exhibit

sponsored by the American Institute of Aeronautics and Astronautics

Reno, Nevada, January 14-17, 2002

National Aeronautics and

Space Administration

Glenn Research Center 
Available from

NASA Center for Aerospace Information 7121 Standard Drive

National Technical Information Service 5285 Port Royal Road Hanover, MD 21076 


\title{
The Role of Water Vapor and Dissociative Recombination Processes in Solar Array Arc Initiation
}

\author{
J. Galofaro and D. Ferguson \\ National Aeronautics and Space Administration \\ Glenn Research Center \\ Cleveland, Ohio 44135 \\ B. Vayner \\ Ohio Aerospace Institute \\ Brook Park, Ohio 44142 \\ W. Degroot \\ Siliconlight, Inc. \\ Sunnyvale, California 94089
}

\begin{abstract}
Experimental plasma arc investigations involving the onset of arc initiation for a negatively biased solar array immersed in low-density plasma have been performed. Previous studies into the arc initiation process have shown that the most probable arcing sites tend to occur at the triple junction involving the conductor, dielectric and plasma [1]. More recently our own experiments have led us to believe that water vapor is the main causal factor behind the arc initiation process. Assuming the main component of the expelled plasma cloud by weight is water, the fastest process available is dissociative recombination $\left(\mathrm{H}_{2} \mathrm{O}^{+}+\mathrm{e}^{-} \rightarrow \mathrm{H}^{*}+\mathrm{OH}^{*}\right)$. A model that agrees with the observed dependency of arc current pulse width on the square root of capacitance is presented. A $400 \mathrm{MHz}$ digital storage scope and current probe was used to detect arcs at the triple junction of a solar array. Simultaneous measurements of the arc trigger pulse, the gate pulse, the arc current and the arc voltage were then obtained. Finally, a large number of
\end{abstract}

measurements of individual arc spectra were obtained in very short time intervals, ranging from 10 to $30 \mu \mathrm{s}$, using a $1 / 4$ meter spectrometer coupled with a gated intensified CCD. The spectrometer was systematically tuned to obtain optical arc spectra over the entire wavelength range of 260 to $680 \mathrm{~nm}$. All relevant atomic lines and molecular bands were then identified.

\section{Nomenclature}

$$
\begin{aligned}
C & =\text { capacitance, } \mu \mathrm{F} \\
I & =\text { current, } \mathrm{A} \\
\Re & =\text { recombination rate, } \mathrm{\# s}^{-1} \\
\gamma & =\text { recombination constant } \mathrm{cm}^{3} \mathrm{~s}^{-1} \\
A & =\text { molecular mass, AMU } \\
N_{e}, & =\text { electron density, } \mathrm{cm}^{-3} \\
R & =\text { radius of sphere, } \mathrm{cm} \\
e & =\text { electronic charge }, q \\
m_{p} & =\text { proton mass, } \mathrm{g} \\
T_{e} & =\text { electron temperature, } \mathrm{eV} \\
K & =\text { Boltzmann constant } \mathrm{J} \mathrm{deg} \mathrm{k}^{-1} \\
V_{e} & =\text { mean electron velocity, } \mathrm{cm} \mathrm{s}^{-1} \\
\sigma & =\text { cross section or overlap, } \mathrm{cm}^{2} \\
U & =\text { scalar field potential, } \mathrm{V} \\
t & =\text { time, } \mathrm{s}
\end{aligned}
$$




\section{Introduction}

The present work is aimed at understanding the underlying cause for the onset of arcing in solar arrays interacting with the space plasma environment. At present, despite the growing volume of experimental data that has been collected on conductor-dielectric initiated solar array arcs [2-8], only two theoretical models come close to describing the process of arc initiation: The first model is based on the hypothesis that a thin insulating layer on the surface of a negatively charged conductor undergoes electrostatic breakdown when the electric field strength becomes high enough [9]. The 1st model is commonly known as the Paschen Discharge Model (PDM). The second model takes into consideration the formation of a strong electric field between the metal, dielectric and plasma junctions $[10,11]$. The 2 nd model has been coined the Triple Junction Model (TJM).

While the PDM gives good estimates for high voltage, it falls short at producing good qualitative results for solar array arcs. The TJM gives good qualitative estimates, but it does not give quantitative agreement with measurements at low voltage. The electric field strength for the case of the TJM can be 2 to 3 orders of magnitude below what is typically needed to initiate an arc [12].

More recently, a modification of the TJM attempted to explain the mechanism of arc inception for the case of low electric field strength. In this new model a field emission correction containing an artificially introduced field enhancement factor was set at approximately 1000 to 2000 [10-14]. The field enhancement factor seems unprovable.

Still more recently, a new correction to the TJM has been reported in an attempt to explain the threshold behavior at the point of arc inception [13]. The current TJM predicts a proportionality between the arc rate and the ion flux to the array. However, this model is not able to explain the onset of the ion avalanche current that gives rise to the high arc currents typically observed in solar arrays.

For the current experiments a small solar array panel (the same solar array panel previously tested in reference [15].) was used for the experiments. We bring to bear a number of optical measurements to identify the presence of the hypothesized absorbed gas molecules.

\section{Experimental Apparatus}

All arc initiation experiments were performed in the small bell jar at the NASA Glenn Research Center Plasma Interaction Facility. The bell jar was equipped with a mechanical roughing pump, a diffusion pump, and an ionization gage for measuring tank pressure. A Penning variety plasma discharge chamber (mounted inside the bell jar) was used as a plasma source for the experiments. An Argon bottle provided the necessary gas neutrals to be ionized by a hot wire filament mounted inside the plasma discharge chamber. A $3 / 4$ inch Langmuir probe (also mounted inside the bell jar) was swept with a programmable power supply and used to obtain the plasma parameters for the experiment. Electron temperature for the experiments ranged between 1.5 and $2 \mathrm{eV}$. Plasma electron number densities ranged between $1.0 \times 10^{4} \mathrm{~cm}^{-3}$ and $8.0 \times 10^{5} \mathrm{~cm}^{-3}$ for the experiments. Figure 1 depicts the experimental apparatus just described. Figure 2 shows a close-up view of the solar array. The solar array is composed of three strings of cells wired in parallel. Each string consists of three individual solar cells mounted in series. Under a full sun each solar cell is capable of delivering $0.53 \mathrm{~V}$ and $300 \mathrm{~mA}$ current. Each string is capable of producing $1.6 \mathrm{~V}$ and $300 \mathrm{~mA}$ of current. The entire array is capable of 


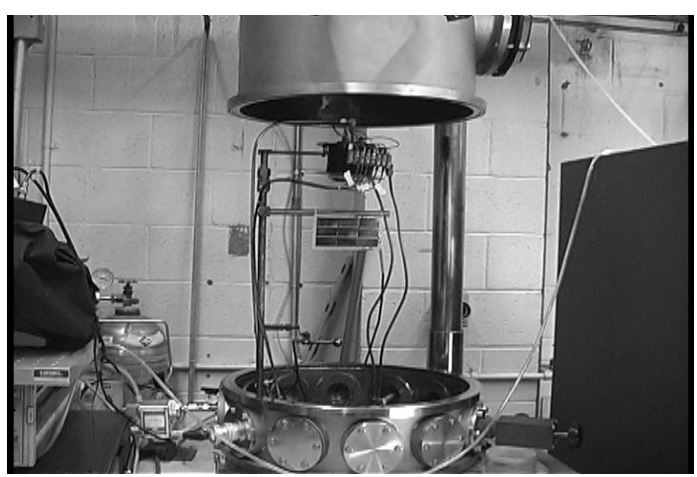

Fig. 1 Bell jar test apparatus used for solar array arcing experiments.

delivering an output voltage of $1.6 \mathrm{~V}$ and $900 \mathrm{~mA}$ of current.

Figure 3 shows the experimental setup used in obtaining the electrical measurements. A capacitor is charged by the bias supply through the resistor and the shorted array contacts are biased to a large negative potential relative to the walls of the bell jar vacuum system. When an arc occurs both the capacitor and solar array are discharged directly through the plasma. The current probe detects the arc and triggers all 4 channels of the oscilloscope.

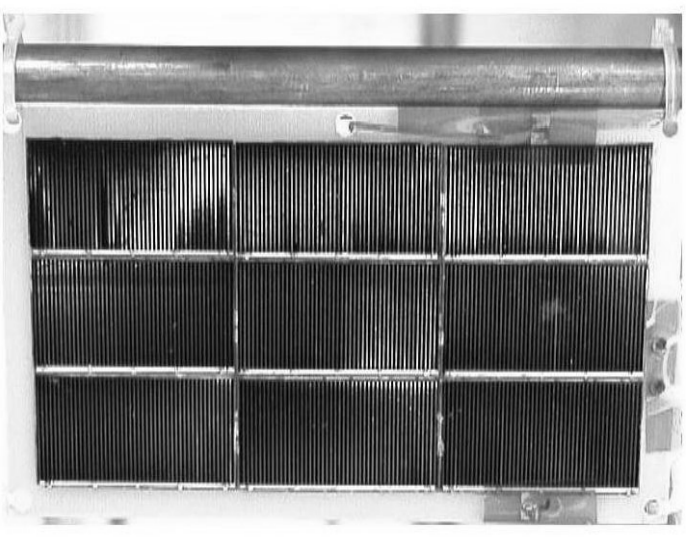

Fig. 2 View of solar array installed inside the vacuum system.

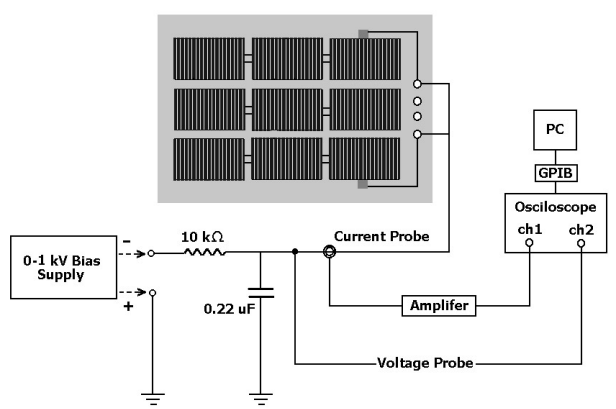

Fig. 3 Diagram of the solar array panel, R-C circuit, current and voltage probes used in obtaining electrical measurements.

Figure 4 shows a diagram of the optical setup used for obtaining individual arc spectra. A $1 / 4$ meter spectrometer with a 1200 lines per mm grating and a gated 1024 by 256 pixel intensified $\mathrm{CCD}$ is used for obtaining the optical measurements. The spectrometer is capable of obtaining readings over the wavelength range of 190 to $920 \mathrm{~nm}$.

The R-C charging circuit (shown in figure 3), a current probe amplifier and oscilloscope combination, provides the

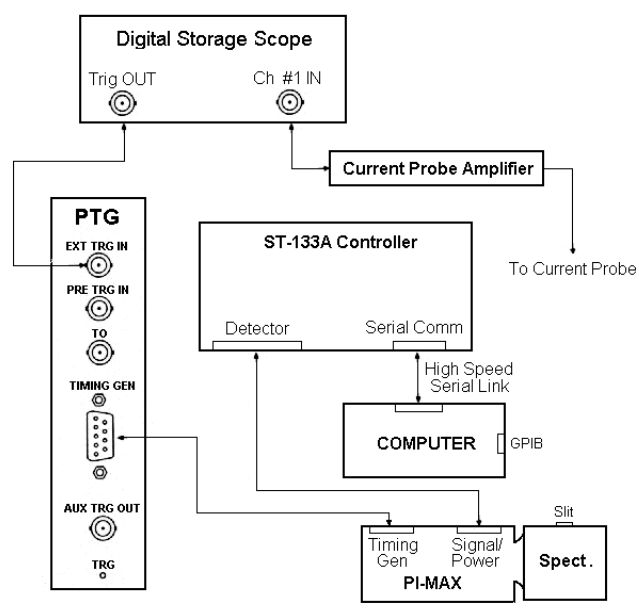

Fig. 4 Diagram showing the ST-133A Controller, PTG, PI-MAX linear array and spectrometer connections used for obtaining individual arc spectra. 
needed output trigger for the Programmable Timing Generator (PTG) shown in figure 4 . The output trigger pulse from the digital storage scope is fed directly to the external trigger input of the PTG. The received input trigger pulse causes the PTG to open the gate of the PIMAX intensified CCD. A signal sent from the ST-133A controller causes the PI-MAX to capture a single arc spectrum for each detected arc event.

\section{Theory}

It has been suggested that the main causal factor behind the arc initiation process is a desorbed molecular gas ionization mechanism (specifically condensed water vapor) at the site of the triple junction. We assume the primary component of the ejected arc plasma by weight is due to $\mathrm{H}_{2} \mathrm{O}$ vapor and $\mathrm{H}_{2} \mathrm{O}^{+}$ions. The fastest process available that is able to describe the arc initiation process is dissociative recombination.

$$
\mathrm{H}_{2} \mathrm{O}^{+}+e^{-} \Rightarrow \mathrm{H}^{*}+\mathrm{OH}^{*}
$$

The steady state volumetric total production rate, $\Re$ for dissociative molecular-ion dominated recombination processes is given by

$$
\Re=<V_{e} \sigma>N_{e}^{2}=\gamma \cdot N_{e}^{2}
$$

The braces in the above equation indicate the expectation value of the product of the mean thermal velocity $V_{e}$ and the overlap integral $\sigma$. (Note that $\Re$ has units of $\# \mathrm{~s}^{-1}$ ) It is well known that the molecular-ion recombination constant $\gamma$ has a strong energy $\left(T_{e}\right)$ dependency [15 and 16].

$\gamma=\left\langle V_{e} \sigma\right\rangle \approx \frac{10^{-7}}{\sqrt{T_{e}}}$ where $T_{e}$ (in units of $\mathrm{eV}$ ) is the electron temperature in the arc plasma. The constant $\gamma$ is in units of $\mathrm{cm}^{3} \mathrm{~s}^{-1}$. Setting $T_{e}=3 \mathrm{eV}$, yields $\gamma=5.8 \cdot 10^{-8} \mathrm{~cm}^{3} \mathrm{~s}^{-1}$ for the recombination rate constant. Assuming, $N_{e}=$ $10^{6} \mathrm{~cm}^{-3}$ and using the calculated value for $\gamma$ above, the total production rate $\mathfrak{R}$ for molecular-ion dissociative recombination processes is of the order of $5.8 \cdot 10^{4} \mathrm{~s}^{-1}$.

Next assume that $N_{e}=\mathrm{f}(\mathrm{t})$. The time dependent form for the dissociative total production rate can be written as $\Re=d N_{e} / d t$ and we are able to directly obtain the following equation.

$$
\frac{d N_{e}}{d t}=-\gamma \cdot N_{e}^{2}
$$

An argument in favor of the desorbed molecular gas ionization process comes from measurements of arc current pulse widths at different capacitances. Vayner, et al. [15] uses the equation (4) to model the square root dependency of capacitance on arc current pulse widths to within an accuracy of 10 percent. The solution to equation (4) with the appropriate boundary condition at $t=0$ in equation (5b) is

$$
N_{e}(t)=\frac{N_{e o}}{1+N_{e o} \cdot \gamma \cdot t}
$$

Where: $\quad N_{e} \mathrm{I}_{t=0}=N_{e o}$

The electric current $I(t)$ to the surface of a hemispheric arc plasma cloud of radius $R(t) \approx(1$ to $2 \mathrm{~cm})$ at the dielectric-conductor junction is simply

$$
I(t)=2 \cdot \pi \cdot R(t)^{2} \cdot N_{e}(t) \cdot e \cdot V_{e}
$$


If it is suggested that the kinetic energy $T_{e}$ (in $\mathrm{eV}$ ) can be written as

$$
T_{e}=\frac{1}{2} \cdot A \cdot m_{p} \cdot V_{e}^{2}
$$

where $\mathrm{A}$ is the gram molecular weight of desorbed gas molecules at the triple junction. The thermal velocity $V_{e}$ is a constant defined from equation (7a) as

$$
V_{e}=\sqrt{\frac{2 \cdot k \cdot T_{e}}{A \cdot m_{p}}}
$$

Assuming the arc plasma propagates a distance $R$ in time $t$ with a velocity $V_{e}$ it is possible to write

$$
R(t)=V_{e} \cdot t
$$

Substituting equations (5a), (5b) and (8) into equation (6) yields the form of the expression given in equation (9).

$$
I(t)=2 \cdot \pi \cdot V_{e}^{3} \cdot t^{2} \cdot \frac{e \cdot N_{e o}}{1+N_{e o} \cdot \gamma \cdot t}
$$

The net electrical charge on the surface of a hemispheric arc plasma cloud may be calculated from equation (10a)

$$
C \cdot U=\int_{0}^{t} I(t) \cdot d t
$$

Where:

$$
\int_{0}^{t} I(t) \cdot d t=2 \cdot \pi \cdot e \cdot V_{e}^{3} \cdot \int_{0}^{t} \frac{N_{e o} \cdot t^{2} \cdot d t}{1+N_{e o} \cdot \gamma \cdot t}
$$

And note, that for $N_{e o} \cdot \gamma \cdot t \gg 1$, it is possible to write

$$
N_{e o} \cdot \gamma \cdot t \approx 1+N_{e o} \cdot \gamma \cdot t
$$

Substitute equation (10b) back into the integral of equation (10a) to get

$$
C \cdot U=\frac{2 \cdot \pi \cdot e \cdot V_{e}^{3}}{\gamma} \cdot \int_{0}^{t} t \cdot d t
$$

Integrating the right hand side of equation (10c) and solving for $t$ yields

$t=\sqrt{\frac{\gamma \cdot C \cdot U}{\pi \cdot e \cdot V_{e}^{3}}}$

Substituting equation (7b) into equation (11) yields the familiar expression previously derived by Vayner.

$t=\left(\frac{\gamma \cdot C \cdot U}{\pi \cdot e}\right)^{\frac{1}{2}} \cdot\left(\frac{A \cdot m_{p}}{2 \cdot k \cdot T_{e}}\right)^{\frac{3}{4}}$

See Vayner, et al. [15] for further discussion and model details.

\section{Electrical Results}

Electrical measurements were taken simultaneously with the arc spectrum for each arc event using a 4-channel digital storage oscilloscope. Plots of arc current and arc voltage were obtained using a current probe to detect the arcs and a voltage probe to track the arc voltage as a function of time. The external trigger pulse and gate monitor pulse are connected to the remaining two channels of the oscilloscope. Each time the oscilloscope is triggered by an arc event, an output trigger pulse is generated by the scope and fed to the external trigger of the Programmable Timing Generator (PTG) See figure 3 . 


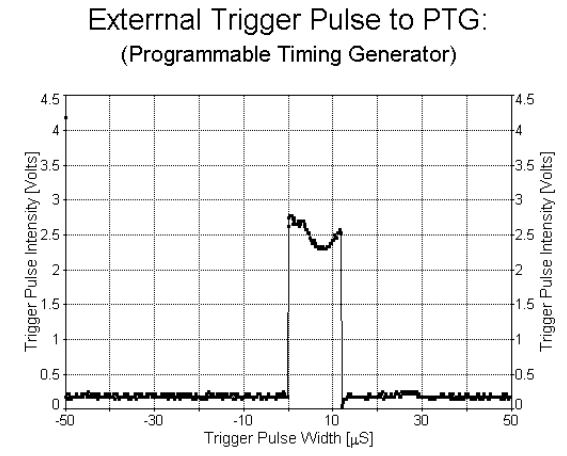

Fig. 5(a)

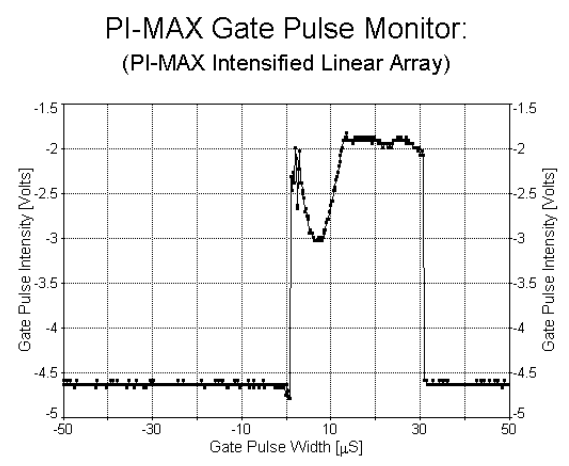

Fig. 5(b)

Figs. 5(a) and 5(b) showing synchronization of the external trigger and gate monitor pulses.

The ST-133 controller was programmed to operate the PI-Max in a pre-open mode and to generate a 10 to $30 \mu$ s wide high voltage gate pulse for each external trigger pulse received (see figure 4). The ST-133 controller records the arc spectra only during the time interval the gate pulse is applied. In order to obtain arc spectra, both the external trigger pulse and the gate pulse need to be synchronized to coincide with the start of the arc event. Note that the gate pulse arrives at the start of the external trigger event in figures 5(a) and 5(b). Figures 5(c) and 5(d) show typical arc current and arc voltage traces that were obtained. Note that the leading edge of the gate pulse corresponds to the time when arc voltage and arc current are approaching their peak values. It was found that optical plasma emissions continue until the arc current is fully discharged.

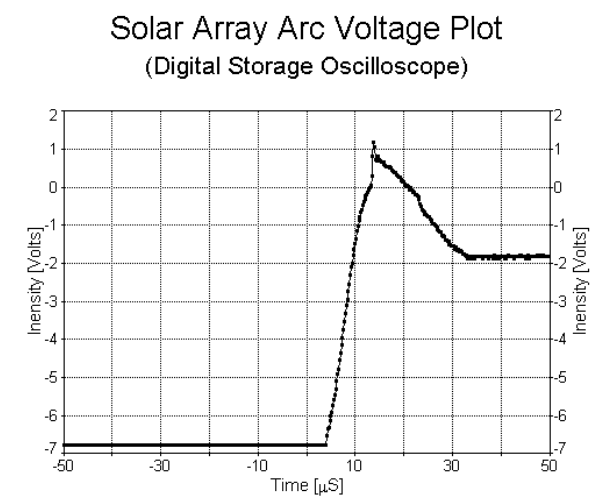

Fig. 5(c)

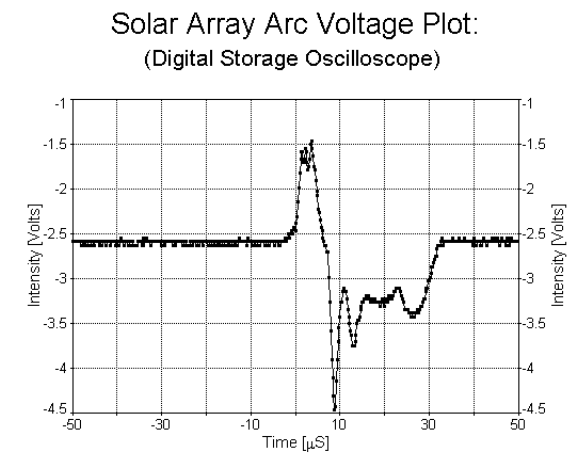

Fig. 5(d)

Figs. 5(c) and 5(d) demonstrating how arc voltage and arc current varies with time.

\section{Optical Spectroscopy Results}

All arc spectra shown in this paper have been obtained using an intensified CCD array cooled to $-20{ }^{\circ} \mathrm{C}$ to reduce the internal noise. 20 rows of vertical pixels $(120+20$ vertical pixels out of a possible 256 pixels and 1024 horizontal pixels out of a $256 \times 1024$ array) are used to keep the signal to noise ratio within acceptable limits. Each spectrum shown covers a wavelength range of $100 \mathrm{~nm}$ divided by 1024 pixels. Thus the 
central wavelength set on the spectrometer corresponds to the horizontal center pixel (512) \pm 40 pixels. The wavelength spreads out from pixel 1 on the far left, through pixel 512, to pixel 1024 on the far right. Spectrometer calibration was then performed using a standard Oriel 6030 argon lamp source and a $50 \mu \mathrm{m}$ slit installed on the spectrometer. Note that each pixel in the PIMAX has a calculated resolution of 0.109 pixels per $\mathrm{nm}$. A minimum of two known lines and the corresponding pixel numbers are needed to manually calibrate a given spectrum. For those instances where only one known line and the corresponding pixel number were known, equation (13) was used to convert pixels to wavelength in nanometers.

$\lambda_{c}=\lambda_{k} \pm 0.109 \cdot\left(P_{c}-P_{k}\right)$

where $\lambda_{\mathrm{k}}$ and $\mathrm{P}_{\mathrm{k}}$ are the known wavelength and known pixel number and $\lambda_{c}$ and $P_{c}$ are the calculated wavelength and pixel number respectively. In practice $P_{c}$ is any pixel number chosen from any pixel feature on the given spectra, such that: $P_{c} \neq P_{k}$. Four to six individual spectra are then gathered at each central wavelength setting to insure that the features present were repeatable and not merely artifacts of the measurement process. Measurements were obtained at the central wavelength starting at $260 \mathrm{~nm}$. The entire optical spectra from 330 to $680 \mathrm{~nm}$ in wavelength were then systematically scanned in $50 \mathrm{~nm}$ increments.

The distance between the spectrometer and the solar array was set to $16 \mathrm{~cm}$. The small chamber size and random arc site locations (from one side of the array to another) caused shifts on the order of $\pm 4 \mathrm{~nm}$ in measured wavelengths. In order to correct this problem the array sample was masked down to the area of one cell leaving one pair of interconnects exposed to the plasma. The reported wavelength values are averaged over the individual wavelength values of individual spectra taken at the same spectrometer central wavelength setting.

To begin our cataloged investigation we searched the NIST Atomic Spectra Data [20] for the two most intensive lines for silver (Ag I: at $328 \mathrm{~nm}$ and at $338 \mathrm{~nm}$, respectively) in the UV spectrum. A line for silver Ag I at $358.6 \mathrm{~nm}$ was also identified. Two more lines for singly ionized silver, $\mathrm{Ag}^{+}(\mathrm{Ag}$ II at $218.7 \mathrm{~nm}$ and for $\mathrm{Ag}$ II at $368.2 \mathrm{~nm}$, respectively) have also been identified from the NIST Data [18]. There appears to be a molecular band at $387 \mathrm{~nm}$ since no atomic lines are tabulated in the NIST UV spectrum at this wavelength. See (Fig.6(a)) for details. (Note: atomic spectra are often characterized by sharp narrow peak, while molecular spectra are often identified by a wide band structure.)

The wide band structure at 302 to $309 \mathrm{~nm}$ is well known as the $\mathrm{OH}$ molecular band. The $\mathrm{OH}$ band is observable in emission in arcs where water vapor is present [19]. The most intensive system of the $\mathrm{OH}$ band occurs at 302.1, 306.3, 306.7, 307.8, and $307.9 \mathrm{~nm}$, which are shown in detail in Fig. 6(b).

Figure 6(c) shows a molecular band at $387 \mathrm{~nm}$ and two wide bands at $434 \mathrm{~nm}$ and at $472 \mathrm{~nm}$. Pearce and Gaydon [19] identify molecular bands for $\mathrm{SiH}$ at $387 \mathrm{~nm}$, a wide band for $\mathrm{CH}$ at approximately $432 \mathrm{~nm}$ and for $\mathrm{SiN}$ at $472 \mathrm{~nm}$. The $\mathrm{SiH}(387 \mathrm{~nm})$ band is often present in silicon arcs in hydrogen (silicon from solar cell and in discharges containing silicon and hydrogen compounds). See Fig. 6(a) and Fig. 6(c). The $\mathrm{CH}$ molecular band often occurs in electrical discharges where carbon molecules and hydrogen molecules are present.

Two atomic lines at approximately 408.71 and $415.87 \mathrm{~nm}$ are also shown in Fig. 6(c). The MIT Wavelength Tables [17] identifies one of two possible lines at 


\section{Solar Array Plasma Arc Atomic and Molecular Spectra}

(Cental Wavelength 330nm, 50 micron Slit)

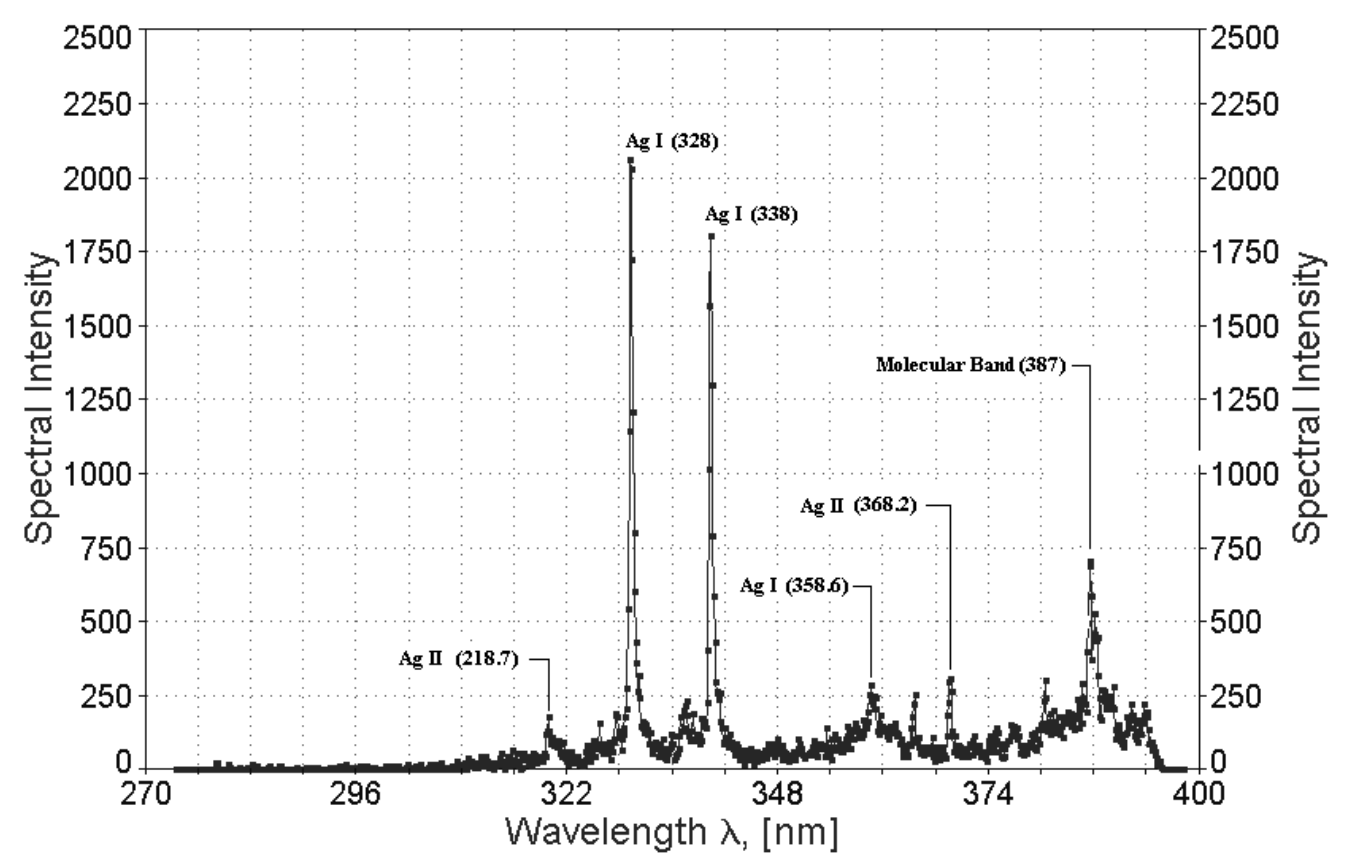

Fig. 6(a)

\section{Molecular OH Band for Solar Array Plasma Arcs}

(Central wavelength $260 \mathrm{~nm}, 50$ micron Slit)

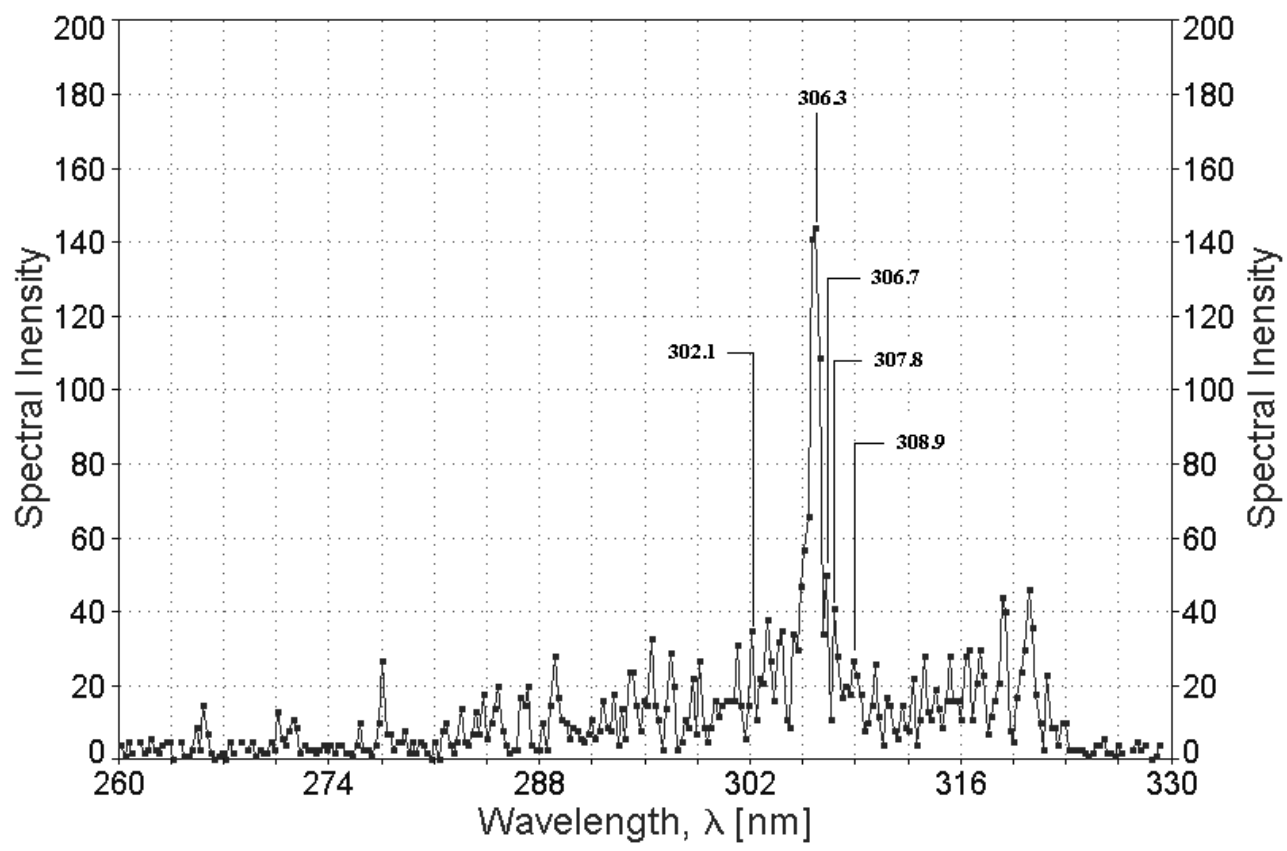

Fig. 6(b) 


\section{Solar Array Plasma Arc Atomic and Molecular Spectra}

(Central Wavelength 430nm, 50 micron Slit)

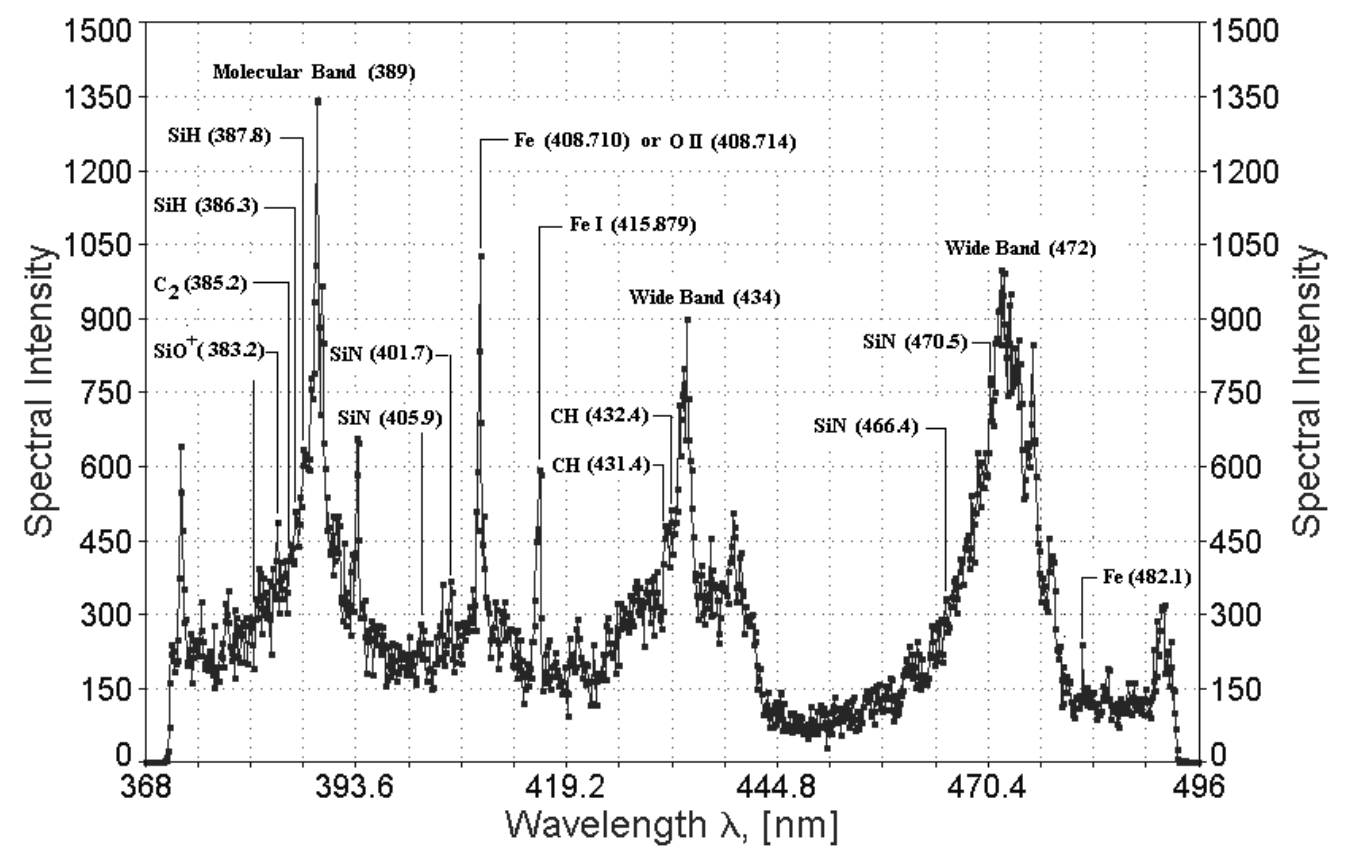

Fig. 6(c)

\section{Atomic Hydrogen Spectrum for Solar Array Plasma Arcs}

(Central Wavelength 680nm, 50 micron Slit)

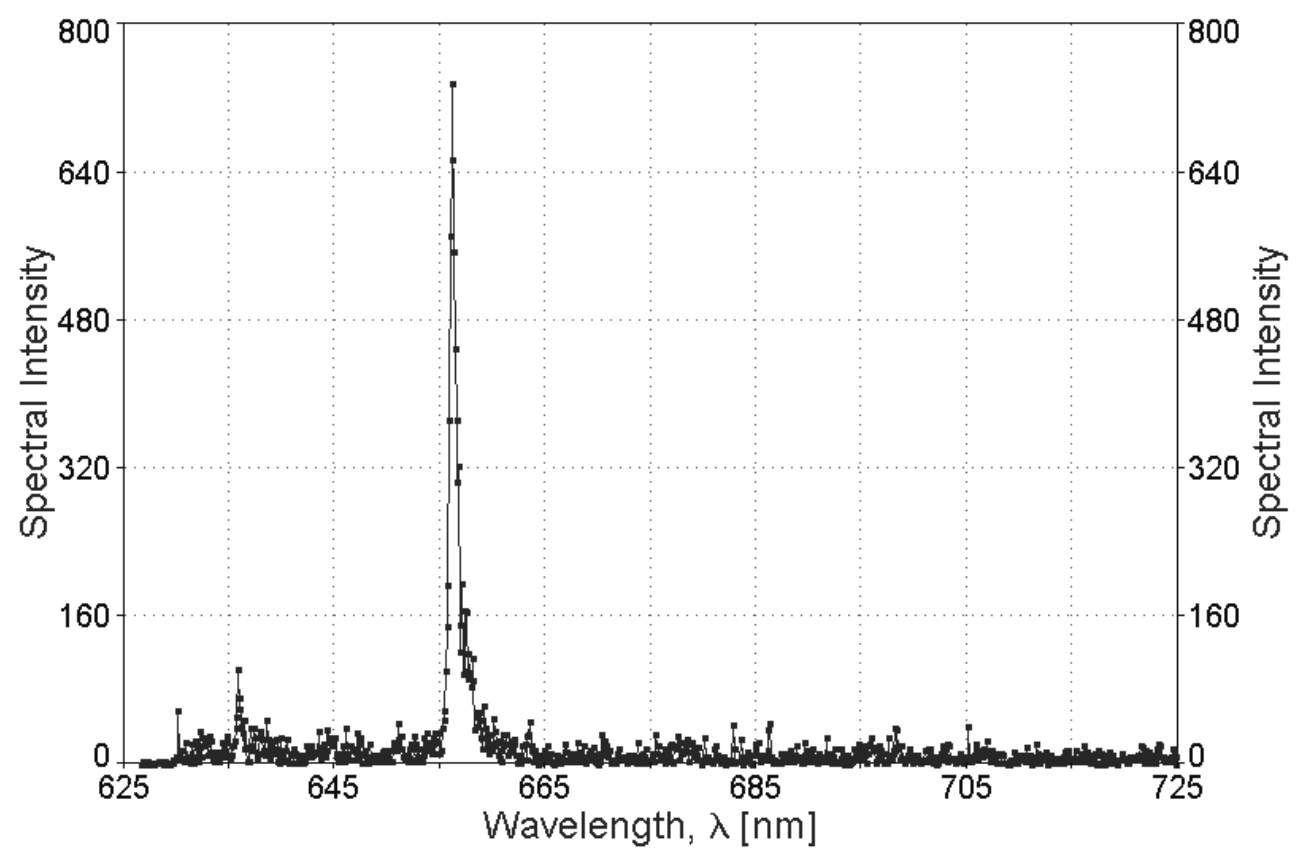

Fig. 6(d) 
$408.7 \mathrm{~nm}$ as either ion $\mathrm{Fe}(408.710 \mathrm{~nm})$ or $\mathrm{O}^{+}(\mathrm{O} \mathrm{II}$ at $408.714 \mathrm{~nm})$. An atomic line for iron (Fe I at $415.879 \mathrm{~nm}$ ) has also been identified in Fig. 6(c). Atomic lines for Nickel $\mathrm{Ni}$ at $480.7 \mathrm{~nm}$ (not shown) and iron Fe at $480.1 \mathrm{~nm}$ (not shown) were observed due to the destruction of the invar electrodes. See Fig. 6(c). A wide band (508 to $511 \mathrm{~nm}$, not shown), consisting of 8 lines of $\mathrm{Fe}$ and $\mathrm{Ni}$ were also observed. A strong atomic line for $H-\alpha$ at $(656.3 \mathrm{~nm})$ corresponding to the $3 \mathrm{~d}-2 \mathrm{p}$ transitions in the hydrogen atom was found. See Fig. 6(d) for details. Finally a strong $\mathrm{H}-\beta$ line at $486 \mathrm{~nm}$ (not shown) was also observed with an intensity of 500 . The $\mathrm{H}$ $486 \mathrm{~nm}$ line corresponds to $4 \mathrm{~d}-2 \mathrm{p}$ transitions of the hydrogen atom.

\section{Summary}

It has been hypothesized that a desorbed gas ionization process occurring at the triple junction of a solar array is responsible for the onset of arc initiation. A simple dissociative recombination mechanism is forwarded which theorizes that the fastest dissociative process available is due to water vapor and $\mathrm{OH}^{*}$ ions. A simple semiempirical model that favors the desorbed gas molecular ionization mechanism was then developed from measurements of the arc current pulse widths at different capacitances. The results from the described model agree with data to a factor within $10 \%$ [15] and presents another argument in favor of the desorbed gas ionization process.

Our spectrometer observations give credence to the hypothesis that supports the desorbed molecular gas ionization process for water vapor at the triple junction of a solar array. We strongly believe that the onset of the arc initiation process is due to absorbed water vapor at site of a triple junction of a solar array immersed in lowdensity plasma.

\section{References}

1. Snyder, D.B., Ferguson, D.C., Vayner, B.V. and Galofaro, J.T. "New Spacecraft-Charging Solar Array Failure Mechanism," 6th Spacecraft Charging Technology Conference, Nov. 2-6, 1998, Air Force Res. Lab, Hanscom AFB, MA, USA.

2. Galofaro, J.T., Doreswamy, C.V., Vayner, B.V. and Snyder, D.B. "Electrical Breakdown of Anodized Coatings in Low-Density Plasmas" Journal of Spacecraft and Rockets, 1999, Vol. 36, No. 2, March-April, pp. 579-585.

3. Vaughn, J.A., Carruth Jr., M.R., Katz, I., Mandell, M.J., and Jongeward, G.A. "Electrical Breakdown Currents on Large Spacecraft in Low Earth Orbit," Journal of Spacecraft and Rockets, 1994, Vol. 31, No. 1, p. 54-59.

4. De la Cruz, C.P., Hastings, D.E., Ferguson, D.C., and Hillard, D.B. "Data Analysis and Model Comparison for Solar Array Module Plasma Interactions Experiment," Journal of Spacecraft and Rockets, 1996, Vol. 33, No. 3, pp. 438-446.

5. Ferguson, D.C. "Solar Array Arcing in Plasmas," NASA CP-3059, 1989, pp. 509.

6. Galofaro, J.T., B.V. Vayner, Degroot, W.A., Ferguson, D.C. Thomson, C.D., Dennison, J.R., and Davies, R.E. "Inception of Snapover and Gas Induced Glow Discharges," NASA/TM-2000-209645 (AIAA Paper 2000-0245). 
7. Vayner, B., Galofaro, J., Ferguson, D., Degroot, W., Thompson, C., Dennison, J., and Davies, R. "The Conductor-Dielectric Junctions in a Low Density Plasma," 1999, NASA/TM-209408 (AIAA Paper 2000-0871)

8. Koons, H.C. "Summary of Environmentally Induced Discharges on the P78-2 (SCATHA) Satellite," Journal of Spacecraft and Rockets, Vol. 22, 1983, p. 425.

9. Parks, E.D., Jongeward, G., Katz, I., and Davis, V.A. "ThresholdDetermining Mechanisms for Discharges in High Voltage Solar Arrays," Journal of Spacecraft and Rockets, 1987, Vol. 24, No. 4, pp. 367-371.

10. Hastings, D.E., Weyl, G., and Kaufman, D. "Threshold Voltage for Arcing on Negatively Biased Solar Arrays," Journal of Spacecraft and Rockets, 1990, Vol. 27, No. 5, pp. 539-544.

11. Cho, M., and Hasting, D.E. "Computer Simulation on HighVoltage Solar Array Arcing Onset," Journal of Spacecraft and Rockets, 1993, Vol. 30, No. 2, pp. 189-205.

12. Vayner, B., Galofaro, J., Ferguson, D., Degroot, W., and Vayner, L. "Arcing Onset on a Solar Array Immersed in a Low Density Plasma," AIAA Paper 2001-0400, 39th AIAA Aerospace Sciences Meeting and Exhibit, Jan. 8-11, Reno, NV.

13. Jongeward, G., and Katz, I. "Effect of Conduction and Ion Current on Solar Array Arc Thresholds," 6th
Spacecraft Charging Technology Conf., Nov. 2-6, 1998, Air Force Res. Lab., Hanscom AFB, MA, USA, p. 42.

14. Vayner, B.V., Ferguson, D.C. Galofaro, J.T. and Degroot, W. "Arcing Onset on a Metal-dielectric Junction Immersed in a Low Density Plasma," XXVth International Conference On Phenomena In Ionized Gasses, No. 5, April 11-19.

15. Vayner, B.V., Galofaro, J. and Ferguson, D. "Arc Inception on a Solar Array Immersed in a LowDensity Plasma," 7th Spacecraft Charging Technology Conference, Noordwijk, Netherlands, April 2327, 2001.

16. Plasma Process Technology Fundamentals, George J. Collins, Colorado State University, Fort Collins, CO (01985, pp. 81-84.

17. Masssachusetts Institute of Technology Wave Length Tables, George R. Harrison, M.I.T. Press, Cambridge, Massachusetts \& London, England, 1960.

18. NIST Spectroscopic Properties of Atoms and Atomic Ions, National Institute of Standards and Technology, U.S. Government Printing Office, Washington.

19. The Identification of Molecular Spectra, Pearce, R.W.B., and Gaydon, A.G., Chapman \& Hall LTD, 3rd Edition, 1963, pp. 246-247. 
Public reporting burden for this collection of information is estimated to average 1 hour per response, including the time for reviewing instructions, searching existing data sources, gathering and maintaining the data needed, and completing and reviewing the collection of information. Send comments regarding this burden estimate or any other aspect of this collection of information, including suggestions for reducing this burden, to Washington Headquarters Services, Directorate for Information Operations and Reports, 1215 Jefferson Davis Highway, Suite 1204, Arlington, VA 22202-4302, and to the Office of Management and Budget, Paperwork Reduction Project (0704-0188), Washington, DC 20503.

\begin{tabular}{|l|l|l|}
\hline 1. AGENCY USE ONLY (Leave blank) & $\begin{array}{c}\text { 2. REPORT DATE } \\
\text { March } 2002\end{array}$ & $\begin{array}{r}\text { 3. REPORT TYPE AND DATES COVERED } \\
\text { Technical Memorandum }\end{array}$ \\
\hline
\end{tabular}

\section{TITLE AND SUBTITLE}

The Role of Water Vapor and Dissociative Recombination

Processes in Solar Array Arc Initiation

\section{6. $\operatorname{AUTHOR(S)}$}

J. Galofaro, B. Vayner, W. Degroot, and D. Ferguson

\section{FUNDING NUMBERS}

WU-744-1A-05-00

\section{PERFORMING ORGANIZATION NAME(S) AND ADDRESS(ES)}

National Aeronautics and Space Administration

John H. Glenn Research Center at Lewis Field

Cleveland, Ohio 44135-3191
8. PERFORMING ORGANIZATION REPORT NUMBER

E-13137

\section{SPONSORING/MONITORING AGENCY NAME(S) AND ADDRESS(ES)}

National Aeronautics and Space Administration

Washington, DC 20546-0001
10. SPONSORING/MONITORING AGENCY REPORT NUMBER

NASA TM-2002-211328

AIAA-2002-0938

\section{SUPPLEMENTARY NOTES}

Prepared for the 40th Aerospace Sciences Meeting and Exhibit sponsored by the American Institute of Aeronautics and Astronautics, Reno, Nevada, January 14-17, 2002. J. Galofaro and D. Ferguson, NASA Glenn Research Center; B. Vayner, Ohio Aerospace Institute, 22800 Cedar Point Road, Brook Park, Ohio 44142; W. Degroot, Siliconlight, Inc., A Cypress Semiconductor Company, 385 Moffett Park Drive, Suite 115, Sunnyvale, California 94089.

Responsible person, Joel Galofaro, organization code 5410, 216-433-2294.

12a. DISTRIBUTION/AVAILABILITY STATEMENT

12b. DISTRIBUTION CODE

Unclassified - Unlimited

Subject Category: 72

Distribution: Nonstandard

Available electronically at http://gltrs.grc.nasa.gov/GLTRS

This publication is available from the NASA Center for AeroSpace Information, 301-621-0390.

13. ABSTRACT (Maximum 200 words)

Experimental plasma arc investigations involving the onset of arc initiation for a negatively biased solar array immersed in low-density plasma have been performed. Previous studies into the arc initiation process have shown that the most probable arcing sites tend to occur at the triple junction involving the conductor, dielectric and plasma. More recently our own experiments have led us to believe that water vapor is the main causal factor behind the arc initiation process. Assuming the main component of the expelled plasma cloud by weight is water, the fastest process available is dissociative recombination $\left(\mathrm{H}_{2} \mathrm{O}^{+}+\mathrm{e}^{-} \rightarrow \mathrm{H}^{*}+\mathrm{OH}^{*}\right)$. A model that agrees with the observed dependency of arc current pulse width on the square root of capacitance is presented. A $400 \mathrm{MHz}$ digital storage scope and current probe was used to detect arcs at the triple junction of a solar array. Simultaneous measurements of the arc trigger pulse, the gate pulse, the arc current and the arc voltage were then obtained. Finally, a large number of measurements of individual arc spectra were obtained in very short time intervals, ranging from 10 to $30 \mu \mathrm{s}$, using a $1 / 4 \mathrm{~m}$ spectrometer coupled with a gated intensified CCD. The spectrometer was systematically tuned to obtain optical arc spectra over the entire wavelength range of 260 to $680 \mathrm{~nm}$. All relevant atomic lines and molecular bands were then identified.

\section{SUBJECT TERMS}

15. NUMBER OF PAGES

Solar array arcing; Arc initiation; Triple junction; Desorbed gas ionization mechanism; Dissociative recombination processes; Atomic spectra; Molecular spectra

\begin{tabular}{|c|c|}
\hline $\begin{array}{c}\text { 17. SECURITY CLASSIFICATION } \\
\text { OF REPORT } \\
\text { Unclassified }\end{array}$ & $\begin{array}{c}\text { 18. SECURITY CLASSIFICATION } \\
\text { OF THIS PAGE } \\
\text { Unclassified }\end{array}$ \\
\hline
\end{tabular}

NSN 7540-01-280-5500

\section{SECURITY CLASSIFICATION OF ABSTRACT \\ Unclassified}

